NBER WORKING PAPER SERIES

\title{
INDIVIDUAL VERSUS AGGREGATE COLLATERAL CONSTRAINTS AND THE OVERBORROWING SYNDROME
}

\author{
Martín Uribe \\ Working Paper 12260 \\ http://www.nber.org/papers/w12260 \\ NATIONAL BUREAU OF ECONOMIC RESEARCH \\ 1050 Massachusetts Avenue \\ Cambridge, MA 02138
}

May 2006

A summary of the present study will appear in the May 2006 issue of the American Economic Review Papers and Proceedings under the title "On Overborrowing." I would like to thank Pepe Auernheimer, Stephanie Schmitt-Grohé, Vivian Yue, Enrique Mendoza, and Fabrizio Perri for comments and discussions, and seminar participants at MIT, NC State University, the 2006 Texas Monetary Conference held at Texas A\&M University, and the 2006 ASSA meeting for comments, and Arthur X. Liu and Javier García-Cicco for research assistance. Newer versions of this paper are maintained at www.econ.duke.edu/ uribe. Telephone: 919660 1888. E-mail: uribe@ duke.edu. The views expressed herein are those of the author(s) and do not necessarily reflect the views of the National Bureau of Economic Research.

(C2006 by Martín Uribe. All rights reserved. Short sections of text, not to exceed two paragraphs, may be quoted without explicit permission provided that full credit, including (C) notice, is given to the source. 
Individual Versus Aggregate Collateral Constraints and the Overborrowing Syndrome Martín Uribe

NBER Working Paper No. 12260

May 2006

JEL No. F41

\begin{abstract}
This paper compares the equilibrium dynamics of an economy facing an aggregate collateral constraint on external debt to the dynamics of an economy facing a collateral constraint imposed at the level of each individual agent. The aggregate collateral constraint is intended to capture an environment in which foreign investors base their lending decisions predominantly upon macro indicators as opposed to individual abilities to pay. Individual agents do not internalize the aggregate borrowing constraint. Instead, in this economy a country interest-rate premium emerges to clear the financial market. The central finding of the paper is that the economy with the aggregate borrowing limit does not generate higher levels of debt than the economy with the individual borrowing limit. That is, there is no overborrowing in equilibrium.

Martín Uribe

Department of Economics

Duke University

Durham, NC 27708-0097

and NBER

uribe@duke.edu
\end{abstract}




\section{Introduction}

A central question in emerging-market macroeconomics is what factors lead countries to accumulate excessive levels of external debt. This question is of relevance because periods of abnormally large capital inflows to emerging markets are more often than not followed by sudden reversals in capital flows, sharp contractions in aggregate activity, exchange-rate collapses, and banking crises (see, for instance, Calvo et al. 2004).

Before the 1990s, existing theoretical explanations of overborrowing emphasize domestic policy failures. McKinnon's (1973) model of deposit guarantees, for example, has been intensively used to understand the effects of financial liberalization in the Southern Cone of Latin America in the 1970s. In McKinnon's model, deposit guarantees induce moral hazard, as banks tend to undertake immoderately risky projects and depositors have less incentives to monitor the quality of banks' loan portfolios. As a result deposit guarantees open the door to excessive lending and increase the likelihood of generalized bank failures.

A second theory of overborrowing that stresses domestic policy imperfections is the temporariness hypothesis due to Calvo (1986). Under this theory, an economic reform, if perceived as temporary by economic agents, can induce a suboptimal boom-bust cycle in capital inflows. Consider, for instance, a temporary reduction in import tariffs. To take advantage of the transitory nature of the trade reform, agents will tend to substitute current spending for future spending, generating current account deficits while the new policy is in effect and a current account reversal when the policy is abandoned. The temporariness hypothesis has been influential in explaining failed trade and financial liberalizations and inflation stabilizations in Latin America in the late 1970s and early 1980s.

the debt crisis of the early 1980s was followed by almost a decade of dry credit conditions for emerging markets. This situation came to an end in the early 1990s when capital flows to the region resumed with vigor. The increased external borrowing was accompanied by large trade imbalances, real-exchange-rate appreciation, and expansion in the nontraded sector. As in the 1980s, this expansionary phase came to an end traumatically, Starting with Mexico in the mid 1990s a number of countries in Latin America, Asia, and eastern Europe faced a sudden discontinuation of capital inflows, reversals in trade flows, large depreciations, significant drops in aggregate activity, and financial stress.

Although domestic policy mismanagement is not ruled out as a factor behind the latest generation of economic crises, researchers, policymakers, and economic observers have increasingly emphasized the role played by foreign lenders. Ferri, Liu, and Stiglitz (1999), for instance, argue that credit rating agencies, such as Standard and Poor's and Moody's, were too procyclical in their rating behavior of emerging-market debt in the 1990s, particu- 
larly in Asia. These authors argue that credit-rating companies were too quick in massively upgrading Asian debt during the period of capital inflows and equally quick in massively downgrading the same assets during the contractionary phase. Because international lending, particularly by institutional investors, is highly sensitive to credit ratings, credit-rating agencies exacerbated the boom-bust cycle in Asia in the 1990s.

More generally, it is argued that emerging markets tend to overborrow when the lending decisions of foreign financial institutions are guided by aggregate indicators of the emerging country's macroeconomic performance and not by careful assessment of individual borrowers' abilities to repay. When lending is based on aggregate indicators overborrowing occurs because individual agents fail to internalize the effect their own borrowing decisions have on the country's aggregate credit conditions. Overborrowing, it is argued, makes emerging countries prone to balance-of-payments crises, or sudden stops, and calls for government policy aimed at putting sand in the wheels of external finance.

The contribution of this paper is to investigate whether lending practices based on aggregate indicators indeed lead emerging countries to overborrow. To this end, I characterize the equilibrium dynamics of a small open economy subject to an aggregate borrowing constraint. I have in mind a situation in which foreign lenders lack the ability or the incentives to monitor individual investment projects in the emerging country and instead base their lending decisions on observation of a few macroeconomic indicators, such as total external debt or domestic stock prices. Individual agents do not internalize the credit constraint. I assume that in this economy credit rationing is implemented through a market mechanism. Specifically, when the aggregate debt limit is reached, an interest-rate premium emerges in the domestic economy inducing individual borrowing decisions to be collectively compatible with the aggregate credit constraint. I compare the equilibrium dynamics of this economy to those of an economy in which the borrowing limit is imposed at the level of each individual agent.

The specific question that my investigation aims to address is whether the economy with the aggregate debt limit tends to overborrow relative to the economy with debt limits imposed at the level of each individual agent. I find that there is no overborrowing in equilibrium. That is, the equilibrium distribution of external debt is the same under an aggregate borrowing limit and under an individual borrowing limit. The reason is that in the economy with the aggregate credit constraint, market incentives, conveyed by the interest rate, induce individual saving decisions that are identical to those caused by the imposition of agent-specific debt limits. The no-overborrowing result holds under two alternative specifications of the debt limit: one in which debt is limited by a constant, and one in which debt is limited by a fraction of the market value of domestic assets. 
Two features of models with debt limits are key in generating no overborrowing. One feature is that when the debt constraint is internalized the opportunity cost of funds is independent of the household's debt position, even for levels of debt arbitrarily close to the ceiling. Only when the debt constraint is binding does the shadow cost of loans adjust upwards. The second theoretical feature that is important in generating the no-overborrowing result is that when the debt limit binds, it does so for all agents at the same time.

I present two theoretical examples showing that once any of the aforementioned two features are absent aggregate debt limits may induce overborrowing in equilibrium. In one example, agents are heterogeneous in their endowments, allowing for the possibility that not all households be financially constrained at the same time. In the second example, households face an interest-rate schedule that is increasing in the external debt position, as in models of sovereign debt à la Eaton and Gersowitz (1981).

The remainder of the paper is organized in six sections. Section 2 presents a simple model of a small open economy facing an aggregate borrowing ceiling. Section 3 presents an economy where the borrowing ceiling is imposed at the individual level. Section 4 establishes analytically the central result of no overborrowing. It shows that when rents from financial rationing accrue to domestic residents, the equilibrium dynamics in the economy with the aggregate debt limit and in the economy with the individual debt limit are identical. Section 5 studies the case in which rents from financial rationing accrue to foreign lenders. In this case, the economies with an individual and an aggregate debt limit can no longer be compared analytically. However, I establish numerically the absence of overborrowing. Section 6 analyzes an economy where external debt is limited by the market value of a domestically owned asset. In this environment the credit limit is time varying and becomes tighter when the market price of domestic assets falls. Section 7 puts the no-overborrowing

result in perspective and explores modifications to the basic framework capable of inducing overborrowing in the presence of aggregate debt limits.

\section{An Economy With An Aggregate Borrowing Ceiling}

Consider an economy populated by a large number of identical households with preferences defined over consumption of a perishable good, $c_{t}$, and labor effort, $h_{t}$, and described by the utility function

$$
E_{0} \sum_{t=0}^{\infty} \theta_{t} U\left(c_{t}, h_{t}\right)
$$


where $U$ denotes the period utility function, which is assumed to be increasing in its first argument, decreasing in its second argument, strictly concave, and twice continuously differentiable. To ensure that the deterministic steady state is independent of the initial asset position, I adopt the standard practice in modeling small open economies of assuming that the subjective rate of discount is a function of endogenous variables (see, for instance, Schmitt-Grohé and Uribe, 2003, and the references cited therein). Specifically, let $\theta_{0}=1$ and $\theta_{t} / \theta_{t-1}=\beta\left(C_{t}, H_{t}\right)$, where $C_{t}$ and $H_{t}$ denote, respectively, aggregate consumption and hours worked. The function $\beta$ is assumed to be decreasing in its first argument and increasing in its second argument. The household takes the evolution of $C_{t}$ and $H_{t}$ as given. The choice of aggregate variables as arguments of the discount factor simplifies the household's optimality conditions. It will become clear that the central result of this paper is robust to assuming that the discount factor is a function of the individual levels of consumption and effort.

Output, denoted $y_{t}$, is produced with a technology that takes labor as the only input. Production is subject to an aggregate, exogenous productivity shock denoted by $z_{t}$. Formally, $y_{t}=e^{z_{t}} F\left(h_{t}\right)$. The production function $F$ is assumed to be positive, strictly increasing, and strictly concave. Allowing for capital accumulation would not alter the main results of the paper.

The only financial asset available to households is a risk-free international bond. The household's sequential budget constraint is given by

$$
\frac{a_{t+1}}{R_{t}}=a_{t}+c_{t}-e^{z_{t}} F\left(h_{t}\right)
$$

where $a_{t}$ denote debt due in period $t$, and $R_{t}$ denotes the gross interest rate on assets held between periods $t$ and $t+1$. Households are assumed to be subject to a no-Ponzi-game constraint of the form $\lim _{j \rightarrow \infty} E_{t} \frac{a_{t+j+1}}{\prod_{s=0}^{j} R_{t+s}} \geq 0$.

The household's problem consists in choosing contingent plans $c_{t}, h_{t}$, and $a_{t+1}$ so as to maximize (1) subject to (2) and the no-Ponzi-game constraint, given the processes $R_{t}$ and $z_{t}$ and the initial condition $a_{0}$. The first-order conditions associated with this problem are (2), the no-Ponzi-game constraint holding with equality, and

$$
\begin{gathered}
-\frac{U_{h}\left(c_{t}, h_{t}\right)}{U_{c}\left(c_{t}, h_{t}\right)}=e^{z t} F^{\prime}\left(h_{t}\right), \\
U_{c}\left(c_{t}, h_{t}\right)=\beta\left(C_{t}, H_{t}\right) R_{t} E_{t} U_{c}\left(c_{t+1}, h_{t+1}\right) .
\end{gathered}
$$

Foreign lenders impose an aggregate borrowing limit on the domestic economy, which stipulates that the aggregate per capita level of external liabilities assumed by the country 
in any period $t \geq 0$, which $\mathrm{I}$ denote by $A_{t+1}$, be no greater than a ceiling $\kappa>0$. That is,

$$
A_{t+1} \leq \kappa
$$

Foreign lenders take the evolution of the country's external debt $A_{t}$ as given. They interpret this variable as an indicator of the strength of the country's fundamentals and are willing to lend funds to domestic residents without restrictions as long as the country's external debt is below the threshold $\kappa$. Individual domestic households also take the evolution of $A_{t}$ as exogenous.

In periods in which the aggregate borrowing ceiling is not binding, foreign investors lend to domestic residents at the world interest rate, which is assumed to be constant and equal to $R^{*}>1$. When the aggregate borrowing limit is binding, the domestic interest rate may adjust upward to ensure market clearing in the domestic financial market. In this case, the economy faces a country interest-rate premium equal to $R_{t}-R^{*}$. It follows that $R_{t}$ must satisfy $R_{t} \geq R^{*}$ and $\left(R_{t}-R^{*}\right)\left(A_{t+1}-\kappa\right)=0$.

\subsection{The Rents From Financial Rationing}

When the domestic interest rate, $R_{t}$, is above the world interest rate, $R^{*}$, a financial rent is generated. Values of $R_{t}$ above $R^{*}$ create pure rents because in this economy there is no default in equilibrium by assumption. The precise way in which these rents are allocated will in general have consequences for aggregate dynamics. Here, I consider two polar cases: on in which all financial rents accrue to foreign lenders, and one in which financial rents accrue entirely to domestic residents.

When financial rents are appropriated by nonresidents, increases in the domestic interest rate entail a resource cost to the domestic economy as a whole. This cost is reflected in an aggregate resource constraint of the form $A_{t+1} / R_{t}=A_{t}+C_{t}-e^{z_{t}} F\left(H_{t}\right)$. Note that this expression features the domestic interest rate, $R_{t}$, instead of the world interest rate, $R^{*}$.

Alternatively, rents from credit rationing may accrue to domestic residents when, possibly because of competition among foreign lenders, domestic financial intermediaries borrow in the world financial market at the rate $R^{*}$. Thus, the country interest-rate premium represents a net rent to domestic financial institutions. I assume that these rents are distributed in a lump-sum fashion among domestic households, who own the domestic financial institutions in equal shares. In this case, the existence of an interest-rate premium does not introduce a resource cost to the domestic economy. The aggregate resource constraint is therefore given by $A_{t+1} / R^{*}=A_{t}+C_{t}-e^{z t} F\left(H_{t}\right)$. Note that this expression features the world interest rate, $R^{*}$, instead of the domestic interest rate, $R_{t}$. 
Because households are homogeneous, in equilibrium individual and aggregate per capita variables are identical. That is $C_{t}=c_{t}, H_{t}=h_{t}$, and $A_{t}=a_{t}$. We are ready to define a competitive equilibria when financial rents accrue to domestic lenders:

Definition 1 (Equilibrium When Rents Accrue Domestically) A stationary competitive equilibrium under an aggregate borrowing ceiling when rents from financial rationing accrue to domestic residents is a set of stationary stochastic processes $\left\{c_{t}, h_{t}, a_{t+1}, R_{t}\right\}_{t=0}^{\infty}$ satisfying

$$
\begin{gathered}
U_{c}\left(c_{t}, h_{t}\right)=\beta\left(c_{t}, h_{t}\right) R_{t} E_{t} U_{c}\left(c_{t+1}, h_{t+1}\right), \\
-\frac{U_{h}\left(c_{t}, h_{t}\right)}{U_{c}\left(c_{t}, h_{t}\right)}=e^{z_{t}} F^{\prime}\left(h_{t}\right), \\
R_{t} \geq R^{*} \\
a_{t+1} \leq \kappa, \\
\left(R_{t}-R^{*}\right)\left(a_{t+1}-\kappa\right)=0 \\
\frac{a_{t+1}}{R^{*}}=a_{t}+c_{t}-e^{z t} F\left(h_{t}\right)
\end{gathered}
$$

given the process $\left\{z_{t}\right\}_{t=0}^{\infty}$ and the initial condition $a_{0}$.

Similarly, competitive equilibria when financial rents accrue to foreign lenders is defined as follows:

Definition 2 (Equilibrium When Rents Accrue to Foreigners) A stationary competitive equilibrium under an aggregate borrowing ceiling when rents from financial rationing accrue to foreign lenders is a set of stationary stochastic processes $\left\{c_{t}, h_{t}, a_{t+1}, R_{t}\right\}_{t=0}^{\infty}$ satisfying conditions (4)-(8) and the resource constraint

$$
\frac{a_{t+1}}{R_{t}}=a_{t}+c_{t}-e^{z_{t}} F\left(h_{t}\right)
$$

given the process $\left\{z_{t}\right\}_{t=0}^{\infty}$ and the initial condition $a_{0}$.

I postpone the characterization of equilibrium in these economies until I described equilibrium in an economy with an internalized borrowing limit. 


\section{An Economy With An Individual Borrowing Ceiling}

Suppose now that lenders impose a debt ceiling at the level of each individual household. That is,

$$
a_{t+1} \leq \kappa
$$

Unlike in the economy with the aggregate debt ceiling, in this economy domestic agents internalize the borrowing constraint. As a result, they take this constraint into account in determining the intertemporal allocation of consumption and financial assets. Accordingly, the household problem consists in maximizing (1) subject to (2) and (11). The optimality conditions associated with this problem are (2), (3), (11), and

$$
\begin{gathered}
U_{c}\left(c_{t}, h_{t}\right)\left[\frac{1}{R_{t}}-\xi_{t}\right]=\beta\left(C_{t}, H_{t}\right) E_{t} U_{c}\left(c_{t+1}, h_{t+1}\right), \\
\xi_{t} \geq 0 \\
\left(a_{t+1}-\kappa\right) \xi_{t}=0
\end{gathered}
$$

where $\xi_{t}$ denotes the Lagrange multiplier associated with the debt constraint (11) divided by the marginal utility of consumption. When $\xi_{t}$ is strictly positive, the debt ceiling is binding and the household faces a shadow interest rate given by $R_{t} /\left(1-R_{t} \xi_{t}\right)$, which is greater than the market interest rate $R_{t}$. This shadow interest rate reflects the fact that at the market interest rate the household would like to borrow beyond the limit $\kappa$.

Foreign lenders supply funds to domestic residents at the world interest rate, $R^{*}$. Therefore, $R_{t}$ equals $R^{*}$ at all dates and states. The following definition of a competitive equilibrium then applies:

Definition 3 (Equilibrium With An Individual Debt Ceiling) A stationary competitive equilibrium under an individual debt ceiling is a set of stationary stochastic processes $\left\{c_{t}, h_{t}, a_{t+1}, \xi_{t}\right\}_{t=0}^{\infty}$ satisfying

$$
\begin{aligned}
U_{c}\left(c_{t}, h_{t}\right)\left[\frac{1}{R^{*}}-\xi_{t}\right]=\beta\left(c_{t}, h_{t}\right) E_{t} U_{c}\left(c_{t+1}, h_{t+1}\right), \\
-\frac{U_{h}\left(c_{t}, h_{t}\right)}{U_{c}\left(c_{t}, h_{t}\right)}=e^{z_{t}} F^{\prime}\left(h_{t}\right), \\
\xi_{t} \geq 0 \\
a_{t+1} \leq \kappa,
\end{aligned}
$$




$$
\begin{gathered}
\left(a_{t+1}-\kappa\right) \xi_{t}=0, \\
\frac{a_{t+1}}{R^{*}}=a_{t}+c_{t}-e^{z_{t}} F\left(h_{t}\right),
\end{gathered}
$$

given the process $\left\{z_{t}\right\}_{t=0}^{\infty}$ and the initial condition $a_{0}$.

We are ready to compare equilibrium dynamics under aggregate and individual debt limits.

\section{An Equivalence Result}

This establishes that the equilibrium processes for debt, consumption, hours, and output in the economy with an individual debt ceiling and in the economy with an aggregate debt ceiling with rents from financial rationing accruing to domestic households are identical. To this end, consider the economy with an individual debt constraint. Definition 3 lists the equilibrium conditions corresponding to this economy. Equations (12) and (14) together with the fact that $U_{c}\left(c_{t}, h_{t}\right)>0$ imply that $\xi_{t} \in\left[0,1 / R^{*}\right)$. Define

$$
R_{t}=\frac{R^{*}}{1-R^{*} \xi_{t}}
$$

Clearly, $\xi_{t}>0$ iff $R_{t}>R^{*}$, and $\xi_{t}=0$ iff $R_{t}=R^{*}$. Use the definition of $R_{t}$ to eliminate $\xi_{t}$ from equilibrium conditions (12), (14), and (16). It follows immediately that the equilibrium conditions of the economy with an individual debt ceiling can be written as:

$$
\begin{gathered}
U_{c}\left(c_{t}, h_{t}\right)=\beta\left(c_{t}, h_{t}\right) R_{t} E_{t} U_{c}\left(c_{t+1}, h_{t+1}\right), \\
-\frac{U_{h}\left(c_{t}, h_{t}\right)}{U_{c}\left(c_{t}, h_{t}\right)}=e^{z_{t}} F^{\prime}\left(h_{t}\right), \\
R_{t} \geq R^{*} \\
a_{t+1} \leq \kappa, \\
\left(R_{t}-R^{*}\right)\left(a_{t+1}-\kappa\right)=0, \\
\frac{a_{t+1}}{R^{*}}=a_{t}+c_{t}-e^{z_{t}} F\left(h_{t}\right) .
\end{gathered}
$$

These expressions are identical to the equilibrium conditions pertaining to the economy with an aggregate debt limit and rents accruing to domestic households, given by equations (4)(9). As a result, the equilibrium behavior of $a_{t}, c_{t}$, and $h_{t}$ are identical in the economy with an individual debt ceiling and in the economy with an aggregate debt ceiling and financial rents owned domestically. 
We conclude that in the economic environment studied here the practice by foreign investors of basing their lending decisions on macroeconomic indicators, as opposed to individual solvency indicators, does not induce overborrowing. The individual incentives created by the market (i.e., by $R_{t}$ ) in the economy with the aggregate debt limit are exactly the same as those emerging from an individual debt limit. Formally, as is clear in the derivation of the equivalence result, the market and social price of external funds are identical in the economy with the aggregate debt limit. The following proposition summarizes the no-overborrowing result:

Proposition 1 (No Overborrowing) The equilibrium dynamics of $c_{t}, h_{t}, y_{t}$, and $a_{t}$ are identical in the economy with an individual debt limit and in the economy with an aggregate debt limit with rents from financial rationing accruing to domestic households.

This proposition is robust to a number of modifications of the basic model within which it was derived. For instance, it can be shown that the equivalence result continues to hold in the context of an economy with capital accumulation. The result can also be shown to be robust to alternative specifications of the discount factor. In particular, when the discount factor is assumed to depend on the individual levels of consumption and effort, as opposed to aggregate measures of these variables. Enriching the sources of uncertainty to include shocks to endowments, tastes, the world interest rate, or the debt limit $\kappa$ would also leave the no-overborrowing result unaltered.

The no-overborrowing result stated in proposition 1 contrasts sharply with the findings of Fernández-Arias and Lombardo (1998). These authors conclude that when agents fail to internalize the debt limit, the economy tends to overborrow. The structure of the model economy used by Fernández-Arias and Lombardo is similar to the one presented here, with three nonessential differences. Namely, their model is cast in perfect foresight and in continuous time, and output is assumed to take the form of an exogenous endowment. The central difference between the Fernández-Arias and Lombardo model and the one I study here has to do with the mechanism through which credit rationing is brought about in the economy with an aggregate debt limit. In the formulation I adopt in this paper, credit rationing is implemented through a market mechanism. The interest rate, $R_{t}$, adjusts to induce agents to borrow an amount that in the aggregate is in line with the credit limit imposed on the country as a whole. In the Fernández-Arias and Lombardo model, credit rationing is not implemented through the price system. Indeed, they assume that the domestic interest rate is always equal to the world interest rate $\left(R_{t}=R^{*}, \forall t\right)$. Instead they impose a credit constraint of the type $a_{t} \leq a_{\tau}, t \geq \tau$, at the level of each individual household, where $\tau$ is the date at which the aggregate borrowing constraint becomes binding, which is known under 
perfect foresight. Agents do not internalize the fact that in equilibrium $a_{\tau}$ must equal $\kappa$. Note that in the Fernández-Arias and Lombardo model agents internalize a substantial part of the credit limit, namely the fact that individual debts cannot grow beyond $a_{\tau}$ after time $\tau$. The only aspect of the debt ceiling agents do not internalize is the ceiling $\kappa$ itself. In the formulation adopted in the present paper, by contrast, agents do not internalize any component of the credit limit. They borrow and lend freely at the interest rate $R_{t}$ (subject, of course, to the standard no-Ponzi-game constraint).

\section{$5 \quad$ Resource Costs}

When rents from financial rationing are appropriated by foreign lenders, it is no longer possible to compare analytically the dynamics of external debt in the economies with the aggregate debt limit and in the economy with the individual debt limit. I therefore resort to numerical methods to characterize competitive equilibria. Preferences and technologies are parameterized as follows: $U(c, h)=\left[c-\omega^{-1} h^{\omega}\right]^{1-\sigma} /(1-\sigma), \beta(c, h)=\left[1+c-\omega^{-1} h^{\omega}\right]^{-\psi}$, and $F(h)=k^{* \alpha} h^{1-\alpha}$, where $\sigma, \omega, \psi, k^{*}$, and $\alpha$ are fixed parameters. Table 1 displays the

Table 1: Parameter Values

\begin{tabular}{|c|c|c|c|c|c|c|c|c|}
\hline$\sigma$ & $\omega$ & $\psi$ & $\alpha$ & $R^{*}$ & $\kappa$ & $k^{*}$ & $\pi_{H H}=\pi_{L L}$ & $z^{H}=-z^{L}$ \\
\hline 2 & 1.455 & 0.0222 & 0.32 & 1.04 & 7.83 & 78.3 & 0.71 & 0.0258 \\
\hline
\end{tabular}

values I assign to these parameters. The time unit is meant to be one year. The values for $\alpha, \omega, \sigma$, and $R^{*}$ are taken from Schmitt-Grohé and Uribe (2003). I set the parameter $\psi$ so as to induce a debt-to-GDP ratio, $a / y$, of 50 percent in the deterministic steady sate. The calibrated value of $\kappa$ is such that in the economy without the debt limit, the probability that $a_{t}$ is larger than $\kappa$ is about 15 percent. The parameter $k^{*}$ can be interpreted as a factor of production that is fixed in aggregate supply, such as land. I set $k^{*}$ so that its market price in the deterministic steady state is unity. The productivity shock is assumed to follow a two-state symmetric Markov process with mean zero. Formally, $z_{t}$ takes on values from the set $\left\{z^{1}, z^{2}\right\}$ with transition probability matrix $\pi$, and $z^{1}, z^{2}$, and $\pi$ satisfy $z^{1}=-z^{2}$ and $\pi_{11}=\pi_{22}$. I set $\pi_{11}$ equal to 0.71 and $z^{1}$ equal to 0.0258 . This process displays the same serial correlation (0.58) and twice as large a standard deviation (2.58 percent) as the one estimated for Canada by Mendoza (1991). My choice of a process for the productivity shock that is twice as volatile as the one observed in a developed small open economy like Canada reflects the view that to a first approximation what distinguishes business cycles in developed and developing countries is that the latter are about twice as volatile as the 
Figure 1: Equilibrium Distribution of External Debt

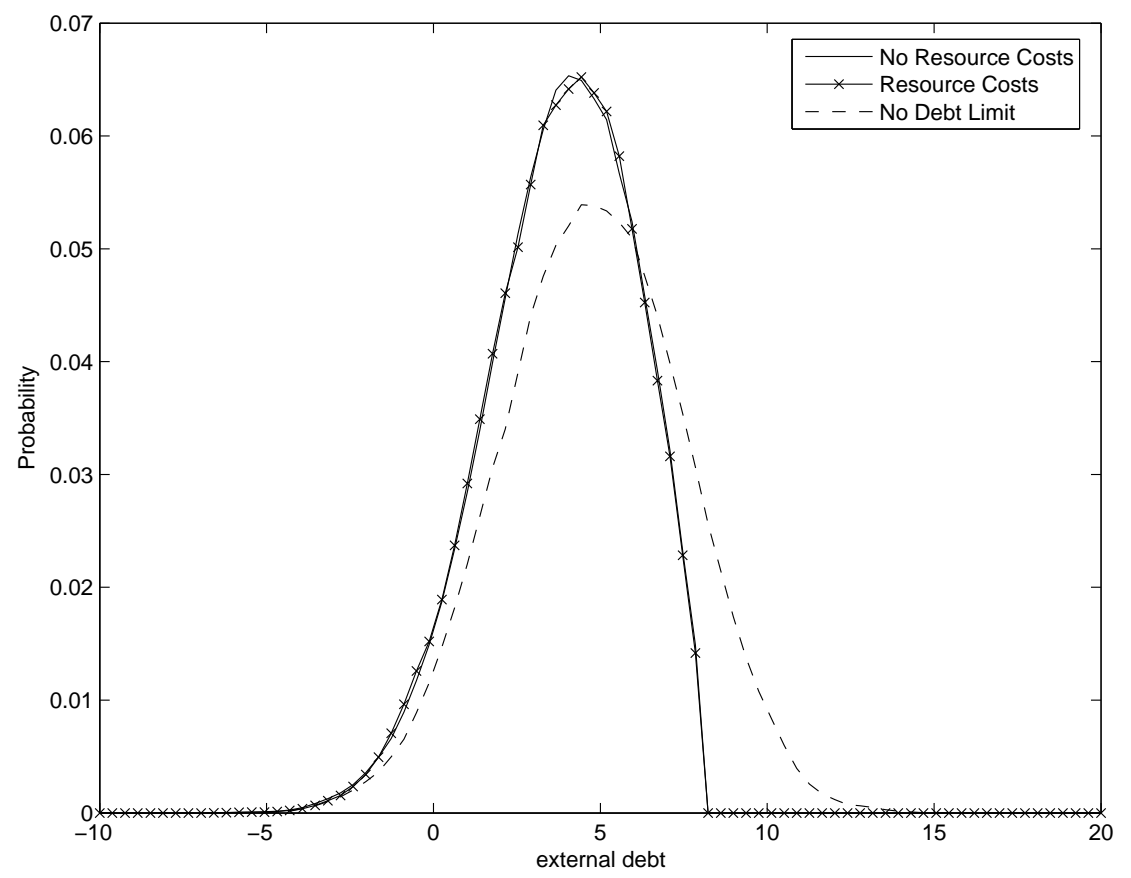

former (Kydland and Zarazaga, 1997).

I solve the model using the Chebyshev parameterized expectations method. The state space is discretized using 1000 points for the stock of debt, $a_{t}$. The parameterization of expectations uses 50 coefficients. I compute the equilibrium for three model economies: An economy with no debt limit, an economy with a debt limit and financial rents accruing to domestic residents, and an economy with a debt limit and financial rents flowing abroad. The procedure approximates the equilibrium with reasonable accuracy. The DenHaan-Marcet test for 5-percent left and right tails yields $(0.047,0.046)$ for the economy without a debt limit, $(0.043,0.056)$ for the economy with a debt limit and rents owned domestically, and $(0.048,0.056)$ for the economy with a debt limit and rents flowing abroad. In conducting this test, I use 1000 simulations of 5000 years each, dropping the first 1000 periods. The Matlab code that implements the numerical results reported in this section are available on my website.

Figure 1 displays with a solid line the equilibrium probability distribution of external debt in the economy with an aggregate debt limit and financial rents from rationing accruing to domestic agents. According to proposition 1, this economy is identical one with a householdspecific debt limit. The figure shows with a dash-crossed line the distribution of debt in the economy with an aggregate debt limit and financial rents accruing to foreign lenders. As a reference, the figure also displays, with a dashed line, the debt distribution in an economy without a debt limit. 
The main result conveyed by the figure is that the distribution of debt in the economy with a debt limit is virtually unaffected by whether financial rents are assumed to flow abroad or stay within the country's limits. The reason behind this result is that the resource cost incurred by the economy when financial rents belong to foreigners is fairly small, about 0.008 percent of annual GDP. This implication is the result of two properties of the equilibrium dynamics. First, the economy seldom hits the debt limit. The debt constraint binds on average less than once every one hundred years. Agents engage in precautionary saving to mitigate the likelihood finding themselves holding too much debt in periods in which the interest rate is above the world interest rate. Second, when the debt limit does bind, it produces a country interest-rate premium of less than 2 percent on average. Finally, the external debt is about 40 percent of GDP when the economy hits the debt limit. It follows that the average cost of remitting financial rents abroad is less than $0.008=40 \times 0.02 \times 100^{-1}$ percent of GDP per year.

The no overborrowing result continues to hold under a more stringent debt limit. I experimented lowering the value of $\kappa$ by 25 percent, from 7.8 to 5.9. This smaller value of the debt limit is such that in the unconstrained economy the probability that $a_{t}$ is larger than $\kappa$ is about 30 percent. Under this parameterization, I continue to find no overborrowing. Specifically, the debt distribution in the economy with an aggregate borrowing limit and rents accruing to foreign lenders is virtually identical to the distribution of debt in the economy with an aggregate debt limit and rents accruing to domestic households, which, as stated in proposition 1 , is identical to the debt distribution in the economy with an individual borrowing limit.

\section{The Role of Stock Prices}

Thus far, I have limited attention to a constant debt limit. In practice, debt limits take the form of collateral constraints limiting the size of debt to a fraction of the market value of an asset, such as land or structures. This type of borrowing limits are also common in recent models of sudden stops. This type of time-varying debt constraints have been shown theoretically to induce more severe financial crises, because states in which the collateral constraint is binding are accompanied by fire sales of collateral and sharp declines in stock

prices (see, for example, Mendoza, 2006). In the context of the present investigation, the relevant central question is whether these fire sales are more or less severe when the collateral constraint is imposed at an aggregate level as opposed to at the level of the individual borrower.

To model a time varying collateral constraint, assume that output is produced via an 
homogeneous-of-degree-one function $F$ that takes labor and land as inputs. Formally, $y_{t}=$ $F\left(k_{t}, h_{t}\right)$. Suppose further that the aggregate per capita supply of land is fixed and given by $k^{*}>0$. Let $q_{t}$ denote the market price of land in terms of consumption goods. Consider first the case in which foreign investors impose a collateral constraint at the country level of the form

$$
A_{t+1} \leq \kappa q_{t} k^{*},
$$

where, as before, $A_{t+1}$ denotes the country's net external debt position due in period $t+1$ and $\kappa>0$ is a parameter. It can be shown that the equilibrium price of land satisfies the following Euler equation:

$$
q_{t}=\beta\left(c_{t}, h_{t}\right) E_{t}\left\{\frac{\lambda_{t+1}}{\lambda_{t}}\left[q_{t+1}+e^{z_{t+1}} F_{k}\left(k^{*}, h_{t+1}\right)\right]\right\} .
$$

Iterating this expression forward yields

$$
q_{t}=E_{t} \sum_{j=1}^{\infty}\left[\prod_{s=0}^{j-1} \beta\left(c_{t+s}, h_{t+s}\right) \frac{\lambda_{t+1+s}}{\lambda_{t+s}}\right] e^{z_{t+j}} F_{k}\left(k^{*}, h_{t+j}\right) .
$$

Intuitively, this expression states that the price of land equals the present discounted value of its future expected marginal products.

A stationary competitive equilibrium with an aggregate collateral constraint and financial rents accruing domestically is given by a set of stationary stochastic processes $\left\{c_{t}, h_{t}, a_{t+1}\right.$, $\left.R_{t}, q_{t}\right\}_{t=0}^{\infty}$ satisfying (4)-(6), (9), (18), and

$$
a_{t+1} \leq \kappa q_{t} k^{*}
$$

and

$$
\left(R_{t}-R^{*}\right)\left(a_{t+1}-\kappa q_{t} k^{*}\right)=0,
$$

with $F\left(h_{t}\right)$ replaced by $F\left(k^{*}, h_{t}\right)$ and $F^{\prime}\left(h_{t}\right)$ replaced by $F_{h}\left(k^{*}, h_{t}\right)$.

Consider now the case in which the collateral constraint is imposed at the level of each borrower. That is, $a_{t+1} \leq \kappa q_{t} k_{t+1}$. In this case, all external loans are extended at the world interest rate $R^{*}$. In states in which the collateral constraint is binding, a shadow interestrate premium $R_{t}-R^{*} \geq 0$ emerges. When households internalize the collateral constraint, the price of land incorporates the financial services provided by this asset in its capacity as collateral. Specifically, with an internalized collateral constraint the pricing equation for 
land becomes

$$
q_{t}\left[1-\kappa\left(\frac{1}{R^{*}}-\frac{1}{R_{t}}\right)\right]=\beta\left(c_{t}, h_{t}\right) E_{t}\left\{\frac{\lambda_{t+1}}{\lambda_{t}}\left[q_{t+1}+e^{z_{t+1}} F_{k}\left(k^{*}, h_{t+1}\right)\right]\right\},
$$

where $R_{t} \geq R^{*}$ denotes the shadow interest rate. Iterate this expression forward to obtain

$$
q_{t}=E_{t} \sum_{j=1}^{\infty}\left[\prod_{s=0}^{j-1} \frac{\beta\left(c_{t+s}, h_{t+s}\right)}{1-\kappa\left(\frac{1}{R^{*}}-\frac{1}{R_{t+s}}\right)} \frac{\lambda_{t+1+s}}{\lambda_{t+s}}\right] e^{z_{t+j}} F_{k}\left(k^{*}, h_{t+j}\right) .
$$

Comparing this expression with its counterpart in the economy with an aggregate borrowing constraint, we observe that the fact that the shadow value of collateral, given by $1 / R^{*}-1 / R_{t}$, is nonnegative implies, ceteris paribus, that the individual agent discounts future marginal products of land less heavily in the economy with the internalized borrowing constraint. In effect, in this case the agent applies the effective discount factor

$$
\frac{\beta\left(c_{t}, h_{t}\right)}{1-\kappa\left(1 / R^{*}-1 / R_{t}\right)} \geq \beta\left(c_{t}, h_{t}\right) .
$$

This difference reflects the fact that when the collateral constraint is internalized the individual agent values the financial service provided by land, namely, collateral.

The above expression for $q_{t}$ does not say that the price of land should be higher in periods in which the collateral constraint is binding. Indeed, we will see shortly that the real value of land falls dramatically during such periods. The above expression does say that during financial crises all other things equal the value of land is likely to be higher in an economy in which the collateral constraint is internalized than in an economy in which it is not. But if in the economy with an individual collateral constraint the value of collateral is higher than it is in an economy with an aggregate collateral constraint, it follows that agents will be able to hold more debt in the former environment. Thus, at least at an intuitive level, one should not expect that the no-overborrowing result of the previous section be overturned by simply replacing the constant debt limit by one increasing in the market value of some domestically owned asset.

A stationary competitive equilibrium with an individual collateral constraint and financial rents accruing domestically is given by a set of stationary stochastic processes $\left\{c_{t}, h_{t}, a_{t+1}\right.$, $\left.R_{t}, q_{t}\right\}_{t=0}^{\infty}$ satisfying (4)-(6), (9), and (19)-(21), with $F\left(h_{t}\right)$ replaced by $F\left(k^{*}, h_{t}\right)$ and $F^{\prime}\left(h_{t}\right)$ replaced by $F_{h}\left(k^{*}, h_{t}\right)$. It is worth noting that the only difference between the equilibrium conditions of the economy with an aggregate collateral constraint and those of the economy with an individual collateral constraint the Euler condition for land. 
To ascertain whether the imposition of an aggregate collateral constraint induces external overborrowing, I compute equilibrium dynamics numerically. I calibrate the economy as in section 5, except for the parameter $\kappa$, which now takes the value $0.1 .^{1}$ I solve the model using the Chebyshev parameterized expectations method. ${ }^{2}$

The top-left panel of figure 2 displays the unconditional distribution of external debt. A solid line corresponds to the economy with an internal collateral constraint, and a dashed line corresponds to the economy with an aggregate collateral constraint. The distribution of debt is virtually identical in the economy with an individual collateral constraint and in the economy with an aggregate collateral constraint. Similarly, as shown in the top-right and bottom-left panels of the figure, whether the collateral constraint is imposed at the individual or the aggregate levels appears to make no difference for the equilibrium dynamics of stock prices or consumption. Note that when the stock of debt is high agents engage in fire sales of land resulting in sharp declines in its market price, $q_{t}$. But the collapse of land prices in periods of high external debt is quantitatively similar in economies with aggregate and individual debt constraints. The contraction in real estate prices is caused by the increase in interest rates (market interest rates in the economy with an aggregate debt limit and shadow interest rates in the economy with an individual debt limit) as the economy approaches the debt limit. ${ }^{3}$ In line with the intuition developed earlier in this section, land prices are indeed higher in the economy with an individual debt limit, but this difference is quantitatively small.

We conclude that the no-overborrowing result is robust to allowing for a debt limit that is increasing in the market value of a fixed factor of production.

\section{Inducing Overborrowing}

The reason why in the of section 2 households do not have a larger propensity to borrow under an aggregate debt limit is that the market and social prices of international liquidity are identical. Two features of the economy studied in this paper are crucial in generating the equality of market and social prices of debt. First, when the borrowing limit is internalized

\footnotetext{
${ }^{1}$ In the deterministic steady state $q_{t}=1$, so that $\kappa q_{t} k^{*}=7.83$, which is the value assigned to $\kappa$ in the economy with the constant debt limit.

${ }^{2}$ The DenHaan-Marcet test for 5-percent left and right tails yields $(0.043,0.061)$ for the economy with an individual collateral constraint, and $(0.048,0.06)$ for the economy with an aggregate collateral constraint. In conducting this test, I use 5000 simulations of 5000 years each, dropping the first 1000 periods. The Matlab code that implements the numerical results reported in this section are available on my website.

${ }^{3}$ Formally, the fire sale of land is driven by a drop in the stochastic discount factor $\beta\left(c_{t}, h_{t}\right) \lambda_{t+1} / \lambda_{t}$, which takes place in both the economy with an aggregate collateral constraint and the economy with an individual collateral constraint.
} 
Figure 2: Equilibrium Under a Time-Varying Collateral Constraint
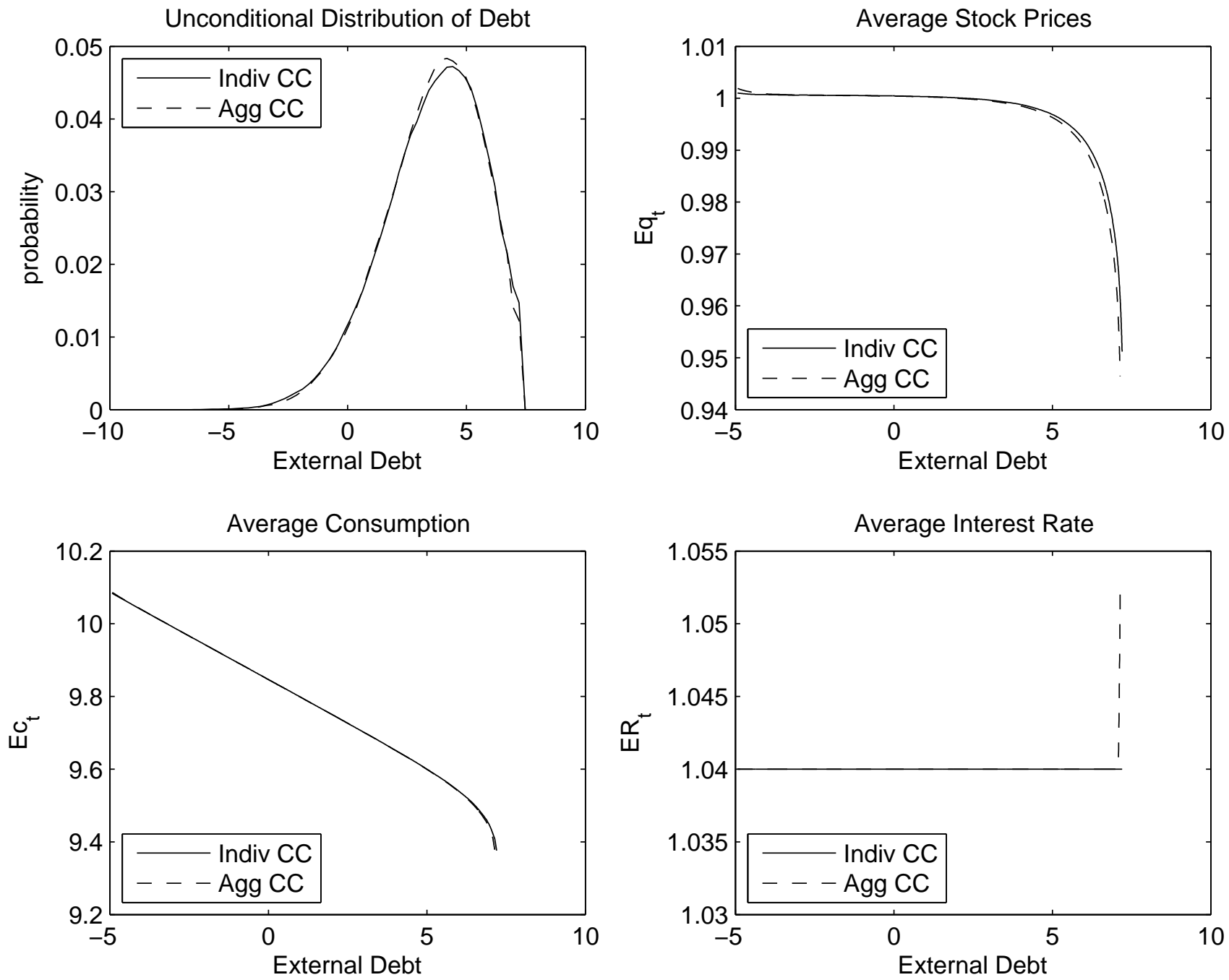

Note: 'Indiv CC' stands for Individual Collateral Constraint, and 'Agg CC' stands for Aggregate Collateral Constraint. 
the shadow price of funds, given by the pseudo interest rate $R^{*} /\left(1-R^{*} \xi_{t}\right)$, is constant and equal to the world interest rate $R^{*}$ except when the debt ceiling is binding. The shadow price of funds equals the world interest rate even as households operate arbitrarily close to the debt ceiling. Second, in the economy with the individual debt constraint, when the debt ceiling binds, it does so for all agents simultaneously. This property is a consequence of the assumption of homogeneity across economic agents.

The absence of either of the abovementioned two features may cause the market price of foreign funds to be below the social price, thereby inducing overborrowing. Here, I provide two theoretical examples in which this is the case. One in which agents are heterogeneous in endowments, and one in which agents face a debt-elastic interest rate.

\subsection{Debt-Elastic Country Premium}

Let the domestic interest rate be given by an increasing function of aggregate external debt of the form $R_{t}=R\left(A_{t+1}\right)$, with $R^{\prime}>0$. Because individual households take the evolution of the aggregate debt position, $A_{t}$, as exogenous, they do not internalize the dependence of the interest rate on their individual debt positions. The reason why the cost of funds is debt elastic is unspecified in this simple setting, but it could be due to the presence of default risk as in models of sovereign debt. Let $A^{*}$ denote the steady-state value of debt in this economy. Then $A^{*}$ must satisfy the condition

$$
1=R\left(A^{*}\right) \beta
$$

where $\beta$ is a constant subjective discount factor. This steady-state condition arises in virtually all formulations of the small open economy with utility-maximizing households (e.g., Schmitt-Grohé and Uribe, 2003). Assume now that the debt-elastic interest-rate schedule is imposed at the level of each individual household, so that $R_{t}=R\left(a_{t+1}\right)$. Let $A^{* *}$ denote the steady-state level of external debt in this economy. It can be shown that $A^{* *}$ is determined by the condition

$$
1-\frac{A^{* *} R^{\prime}\left(A^{* *}\right)}{R\left(A^{* *}\right)}=R\left(A^{* *}\right) \beta .
$$

Clearly, the fact that $R^{\prime}>0$ implies that

$$
A^{*}>A^{* *} \text {. }
$$


That is, the economy with the financial externality generates overborrowing. ${ }^{4}$ We note that in the economy with the aggregate debt limit the market price of foreign funds, $R\left(A_{t+1}\right)$, is strictly lower than the social cost of foreign funds, given by $R\left(A_{t+1}\right) /\left[1-A_{t+1} R^{\prime}\left(A_{t+1}\right) / R\left(A_{t+1}\right)\right]$. This discrepancy, which is key in generating overborrowing, is absent in the economy of the previous sections.

\subsection{Heterogeneous Agents}

The following example describes a situation in which overborrowing occurs because debt limits do not bind for all agents at the same time. The example is in the context of a twoperiod, endowment economy without uncertainty. The economy faces a constant debt ceiling $\kappa$ per capita. There is a continuum of agents of measure one, and agents are heterogeneous. The central result obtains under a variety of sources of heterogeneity, such as differences in endowments, preferences, or initial asset positions. Here, I assume that agents are identical in all respects except their period-2 endowments. Specifically, all households receive the same endowment of $y$ units of goods in period 1 , but in period 2, half of the households receive an endowment of $y^{a}>y$ and the other half receive a smaller endowment of $y^{b}<y^{a}$. Agents receiving the larger future endowment have a stronger incentive to borrow in period 1 to smooth consumption over time.

We have in mind a situation in which in the absence of a debt ceiling households with high expected endowment consume $c^{a}>y+\kappa$ units in period 1 and the rest of the households consume $c^{b}<y+\kappa$ units. Figure 3 depicts the equilibrium in the absence of a debt constraint. In this case, aggregate external debt per capita equals $A^{u}=\left(c^{a}+c^{b}\right) / 2-y$.

When the borrowing ceiling $\kappa$ is imposed at the level of each individual household, half of the households - those with high period-2 endowment-are constrained and consume $y+\kappa$ units, whereas the other half is unconstrained and consumes $c^{b}$. Aggregate external debt per capita equals $A^{i}=\left(\kappa+c^{b}-y\right) / 2<A^{u}$. Clearly, we also have that $A^{i}<\kappa$.

Now suppose that the debt ceiling is imposed at the aggregate level, Here two alternative situations are possible. One is that the aggregate debt limit is not binding. This case takes place when in the absence of a debt constraint aggregate per capita debt does not exceed the ceiling. That is, when $A^{u} \leq \kappa$. In this case, the equilibrium interest rate equals the world interest rate $R^{*}$, and consumption of each agent equals the level attained in the absence of any borrowing constraint. External debt is given by $A^{a}=A^{u}>A^{i}$.

Alternatively, if the aggregate level of external debt in the unconstrained environment

\footnotetext{
${ }^{4}$ Auernheimer and García-Saltos (2000) derive a similar result in a model in which the interest rate depends on the leverage ratio. That is, $R_{t}=R\left(\frac{A_{t+1}}{q_{t} k^{*}}\right)$ in the case of an aggregate debt limit, and $R_{t}=$ $R\left(\frac{a_{t+1}}{q_{t} k_{t+1}}\right)$ in the case of an individual debt limit.
} 
Figure 3: Overborrowing in an Economy with Heterogeneous Agents
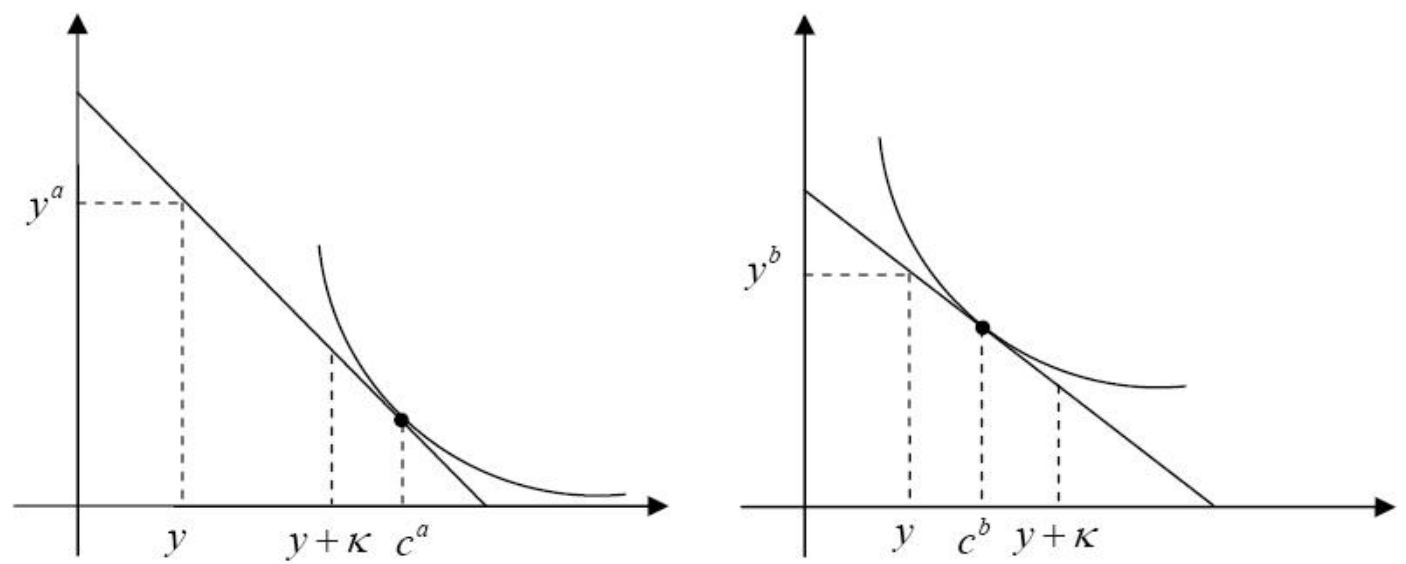

exceeds the ceiling (i.e., if $A^{u}>\kappa$ ), then the economy is financially rationed, the domestic interest rate exceeds the world interest rate, and aggregate borrowing per capita is given by $A^{a}=\kappa>A^{i}$. Therefore, regardless of whether the aggregate debt limit is binding or not, external borrowing is higher when the debt ceiling is imposed at the aggregate level.

Therefore, the combination of heterogeneous consumers and debt limits imposed at the aggregate level induces overborrowing in equilibrium. Overborrowing occurs because of a financial externality. Specifically, the group of more frugal consumers provides a financial service to the group of more lavish consumers by placing comparatively less pressure on the aggregate borrowing constraint. This service, however, is not priced in the competitive equilibrium. ${ }^{5}$

We close this section with a brief comment on the concept of overborrowing when agents are heterogeneous. The term overborrowing has a negative connotation, referring to a suboptimal amount of external financing. In the models with homogeneous agents and a constant debt limit studied earlier in this paper, one can safely interpret any difference in the distribution of external debt in the economies with aggregate and individual debt limits as suboptimal, or overborrowing. This is because the competitive equilibrium associated with the economy featuring individual debt limits coincides with the optimal allocation chosen

\footnotetext{
${ }^{5}$ Interestingly, economic heterogeneity, although of a different nature, is also the root cause of overborrowing in the dual-liquidity model of emerging-market crisis developed by Caballero and Krishnamurthy (2001). In their model, there is heterogeneity in the provision of liquidity across assets. Some assets are recognized as liquid collateral by both domestic and foreign lenders, while other assets serve as collateral only to domestic lenders. Caballero and Krishnamurth show that in financially underdeveloped economies this type of heterogeneity produces an externality whereby the market price of international liquidity is below its social marginal cost.
} 
by a social planner that internalizes the debt limit. ${ }^{6}$ When agents are heterogeneous it is not necessarily the case that the debt distribution associated with the economy featuring an aggregate debt limit is less desirable than the one implied by the economy with an individual debt limit. To see this, suppose, for instance, that in the economy analyzed in this section the social planner cared only about the well being of agents with high period-2 endowments. In this case, the social planner would favor the equilibrium associated with an aggregate borrowing limit over the one associated with an individual debt limit.

\footnotetext{
${ }^{6}$ As noted by Auernheimer and García-Saltos (2000), this is not the case when debt is limited by the value of capital. For in this case agents take as given the price of land, $q_{t}$, which appears in the collateral constraint. The social planner, by contrast, takes $q_{t}$ as endogenous.
} 


\section{References}

Auernheimer, L. and R. García-Saltos, "International Debt and the Price of Domestic Assets," IMF Working Paper wp/00/177, October 2000.

Caballero, Ricardo and Arvind Krishnamurthy, "International and Domestic Collateral Constraints in a Model of Emerging Market Crises," Journal of Monetary Economics 48, December 2001, 513-548.

Calvo, Guillermo A., "Temporary Stabilization: Predetermined Exchange Rates," Journal of Political Economy, 1986, 94, 1319-1329.

Calvo, G. A., A. Izquierdo, and L. F. Meja, "On the Empirics of Sudden Stops: The Relevance of Balance-Sheet Effects," NBER Working Paper No. 10520, 2004.

Eaton, J. and M. Gersowitz, "Debt with Potential Repudiation: Theoretical and Empirical Analysis," Review of Economic Studies 47, 1981, 289-309.

Fernández-Arias, Eduardo and Davide Lombardo, "Private External Overborrowing in Undistorted Economies: Market Failure and Optimal Policy," manuscript, March 1998.

Kydland, Finn E. and Carlos E. J. M. Zarazaga, "Is the business cycle of Argentina "different"?," Economic \&3 Financial Review, Q-IV, 1997, 21-36.

McKinnon, Ronald I., Money and Capital in Economic Development, Brookings Institution Press: Washington, DC, 1973.

Mendoza E.G., "Real Business Cycles in a Small Open Economy," American Economic Review, 81, 1991, 797-818.

Mendoza, Enrique G., "Endogenous Sudden Stops in a an Equilibrium Model of the Business Cycle: Fisher's Deflation of Tobin's Q," manuscript, University of Maryland and International Monetary Fund, April 2006.

Ferri, G., L. G. Liu, and J. E. Stiglitz, "The Procyclical Role of Rating Agencies: Evidence from the East Asian Crisis," Economic Notes 28, 1999, 335-355.

Schmitt-Grohé, Stephanie and Martín Uribe, "Closing Small Open Economy Models," Journal of International Economics, 61, October 2003, 163-185. 